\title{
Madrasah Teachers' TPACK: To What Extent It Facilitates Students' Learning for Literacy?
}

\author{
Lilik Huriyah $^{1, *}$ Zulfahmi Alwi $^{2}$, Nuansa B. Segara ${ }^{3}$ Saifudin Saifudin ${ }^{4}$, \\ Shofar S. Bisri ${ }^{5,}$ Ida Zubaidah ${ }^{6}$ \\ ${ }^{1}$ Department of Management \& Islamic Education, UIN Sunan Ampel Surabaya, Surabaya, Indonesia \\ ${ }^{2}$ Department of Islamic Family Law, UIN Alauddin Makassar, Makassar, Indonesia \\ ${ }^{3}$ Department of Social Studies, State University of Surabaya, Surabaya, Indonesia \\ ${ }^{4}$ MAN 2 Kudus, Kementerian Agama Kudus, Kudus, Indonesia \\ ${ }^{5}$ Kementerian Agama, Kementerian Agama Tegal, Tegal, Indonesia \\ ${ }^{6}$ Pancasila and Civic Education, Universitas Islam Blitar, Blitar, Indonesia \\ *Corresponding author. Email: lilikhuriyah@gmail.com
}

\begin{abstract}
Teachers must be proficient not only in subject matter and pedagogy, but also in technology expertise, in order to design lessons holistically in this time of pandemic. This study looked at 80 teachers from 65 madrasahs (Islamic school) in East Java who took part in PPG (Teacher Professional Education Program) at the LPTK (Institute of Teachers' Education) UIN Sunan Ampel Surabaya in 2021. In this study, the data were analyzed by data reduction, data visualization, and drawing conclusions. The results of the research discussion indicate that madrasah teachers' ability to use Technological Pedagogical and Content Knowledge (TPACK) is still limited to 18.75 percent. Meanwhile, good TPACK ability reached $60 \%$, while quiet TPACK ability reached 21.25 percent. Many variables influence this, including rapid technology advancements, the availability of numerous applications, support from school leaders, school infrastructures, and teachers who are still in their early years of teaching.
\end{abstract}

Keywords: TPACK, Madrasah teachers, Teachers' capability.

\section{INTRODUCTION}

One of the objectives of $21^{\text {st }}$ century education is that teachers must grasp subject, pedagogy, and technology in the learning process at the same time. Teachers must be well-versed in lesson planning and have the skills to do so. They are not only competent in content knowledge and pedagogy, but also have technology skills [1]. Due to the integration of these three abilities, then emerged the term TPACK in the field of education. TPACK is the ability of teachers to use technology by paying attention to the content and pedagogical aspects $[2,3]$.

In fact, many teachers and prospective teachers still haven't grasped TPACK or are just at a beginner's level. The study of Biology teachers is one of the sample instances related to the TPACK research ability. Biology teachers' ability to comprehend material/content knowledge (CK) is rated as good by 76 percent. The pedagogical knowledge (PK) score of the teacher is 52 percent. The percentage of people who have technological knowledge (TK) is $43 \%$. The TPACK knowledge score of the teacher is $53 \%$ [4].

This does not, however, mean that all teachers are unable to use TPACK effectively. According to several additional research, teachers' TPACK abilities are extremely varied. Teachers have used technology-based media in their classrooms in 83 percent of cases, and 85 percent can create simple technology-based learning media. In the very good category, the average percentage of TPACK competency in biology teacher learning media is 86.87 percent [5].

The data for this study were collected on the teacher's skill in the field of TPACK as well as the TPACK component's ability. TPACK consists of three main components, namely content knowledge, pedagogic knowledge, and knowledge of technology (technological knowledge) [7-9]. The combination of these three components forms PCK (Pedagogical Content Knowledge), TCK (Technological Content Knowledge) 
and TPK (Technological Pedagogical Knowledge), and TPACK (Technological Pedagogical and Content Knowledge) [10,11]. In the table below, each of these components is described in detail:

Table 1. Scope of TPACK components

\begin{tabular}{|c|c|}
\hline Components & Scope of TPACK components \\
\hline $\begin{array}{l}\text { Content } \\
\text { knowledge } \\
(\mathrm{CK})\end{array}$ & $\begin{array}{l}\text { Knowledge about the material of } \\
\text { subject matter which is going to be } \\
\text { taught. }\end{array}$ \\
\hline $\begin{array}{l}\text { Pedagogical } \\
\text { knowledge } \\
\text { (PK) }\end{array}$ & $\begin{array}{l}\text { Knowledge about, processes, } \\
\text { practices, and methods in learning. In } \\
\text { other words, pedagogic knowledge is } \\
\text { an understanding that must be } \\
\text { possessed by teachers about } \\
\text { methods, techniques, classroom } \\
\text { management, and approaches in the } \\
\text { learning process. }\end{array}$ \\
\hline $\begin{array}{l}\text { Technological } \\
\text { knowledge (TK) }\end{array}$ & $\begin{array}{l}\text { Knowledge of various digital } \\
\text { technologies such as computers, } \\
\text { internet, digital video, software } \\
\text { applications, or the ability to adapt } \\
\text { and learn new technologies. }\end{array}$ \\
\hline $\begin{array}{l}\text { Pedagogical } \\
\text { content } \\
\text { knowledge } \\
\text { (PCK) }\end{array}$ & $\begin{array}{l}\text { The relationship between basic } \\
\text { knowledge of content and pedagogy } \\
\text { applied by teachers in the classroom. }\end{array}$ \\
\hline $\begin{array}{l}\text { Technological } \\
\text { content } \\
\text { knowledge } \\
\text { (TCK) }\end{array}$ & $\begin{array}{l}\text { Relationship between technology and } \\
\text { material content. Good knowledge of } \\
\text { technology will have a good impact } \\
\text { on the ability to convey material well } \\
\text { so that it is easy to understand. In } \\
\text { addition, with this ability, the teacher } \\
\text { will be able to determine the right } \\
\text { media to deliver the material to be } \\
\text { taught [8]. }\end{array}$ \\
\hline $\begin{array}{l}\text { Technological } \\
\text { Pedagogical } \\
\text { Knowledge } \\
\text { (TPK) }\end{array}$ & $\begin{array}{l}\text { The ability that expresses the } \\
\text { interrelationship between technology } \\
\text { and pedagogy. With the ability, this } \\
\text { enables prospective teachers to use } \\
\text { technology to achieve pedagogical } \\
\text { goals. Using technology will make it } \\
\text { easier for teachers to create new } \\
\text { methods in the classroom. }\end{array}$ \\
\hline
\end{tabular}

\begin{tabular}{|l|lr|}
\hline $\begin{array}{l}\text { Technological } \\
\text { Pedagogical }\end{array}$ & \multicolumn{2}{|c|}{ Knowledge is a combination of each } \\
Content and & field of knowledger (content \\
Knowledge & knowledge, pedagogical knowledge, \\
(TPACK) & technological knowledge, \\
& $\begin{array}{l}\text { pedagogical content knowledge, and } \\
\text { technological content knowledge) by } \\
\text { focusing on the use of technology to } \\
\text { teach content and achieve } \\
\text { pedagogical goals. }\end{array}$ \\
\hline
\end{tabular}

Due to the enormous number of madrasah in Indonesia, the question raised on how is the picture of madrasah teachers' TPACK abilities in Indonesia? Indonesia has 49,337 madrasahs, not including Raudhatul Athfal (playgroup or kindergarten) [6]. From the total number of madrasah, only $7.9 \% \quad(3,886$ madrasah) have the status as state madrasah. While the rest, most of them, $92.1 \%$ (45.451) are private madrasah. The purpose of this study is to discover and describe the TPACK level of madrasah teachers, as well as the factors that influence their TPACK level.

\section{METHODS}

This study is descriptive qualitative research. In this study, 80 religion teachers from 65 madrasahs in East Java were examined. The teachers in this study were madrasah teachers who took part in PPG (Teacher Professional Education Program) at the LPTK (Institute of Teachers' Education) UIN Sunan Ampel Surabaya in 2021. This research data collection uses documentation, that is the work of madrasah teacher learning videos and google form questionnaires to influence the factors that affect the TPACK ability level of madrasah teachers who took part in PPG at UIN Sunan Ampel Surabaya. In addition, data mining was also carried out through interviews with madrasah teachers participating in PPG about their TPACK abilities. There are 80 teaching practice videos of madrasah teachers. Each teacher in this study made one learning video in the class. The duration of the video ranges from 10-15 minutes. This video contains teacher activities in teaching students, which consists of a preliminary, core, and closing activities.

Furthermore, to get data about things that affect the TPACK of madrasah teachers, the researchers used questionnaires and interviews. Before the questionnaire was given to madrasah teachers, the questionnaire was validated by 3 people; 2 material experts and 1 media expert. The research questionnaire contains the names of participants, the school where they teach, the school status; public or private schools, years of teaching, education and scientific background, factors that affect their TPACK abilities, training that have been attended, and leadership facilities in developing teacher abilities. 
Whereas the interviews asked about things that affect teachers' TPACK abilities. Meanwhile, from the video of teacher teaching practice, it can be seen about the teacher's ability in terms of Content Knowledge (CK), Pedagogical Knowledge (PK), Technological Knowledge (TK), Pedagogical Content Knowledge (PCK), Technological Content Knowledge (TCK), Technological Pedagogical Knowledge (TPK), and Technological Pedagogical Content Knowledge (TPACK). The data analysis used is by reducing the research data from the interview which is considered not synchronous. Furthermore, it is presented research data which is about the level of TPACK ability of madrasah teachers and the factors that influence it and draws conclusions. To ensure that these data are valid, the researcher triangulates sources and extends the research time.

\section{RESULTS AND DISCUSSION}

\subsection{The Result of Madrasah Teachers' TPACK}

In this study, the TPACK abilities of 80 religion teachers in madrasah were classified into 5 categories, namely very good, good, poor, poor, and very poor. Based on the results of research on 80 madrasah teachers in East Java who took part in PPG of LPTK at UIN Sunan Ampel Surabaya in 2021, they are as follows:

From table 2 below, it can be understood that the level of ability of madrasah teachers in East Java participating in PPG of LPTK at UIN Sunan Ampel Surabaya in terms of TPACK is mostly good (60\%), very good at $18.75 \%$, and 17 people are quite good or $21.25 \%$.

From the research data explanation above, it can be known that the ability of content knowledge (Content Knowledge/CK), knowledge of pedagogy (Pedagogical Knowledge/PK), and knowledge of technology (Technological Knowledge/TK), Pedagogical Content Knowledge (PCK), Technological Content Knowledge (TCK), Technological Pedagogical Knowledge (TPK), and Technological Pedagogical and Content Knowledge $(T P A C K)$ is as follows:

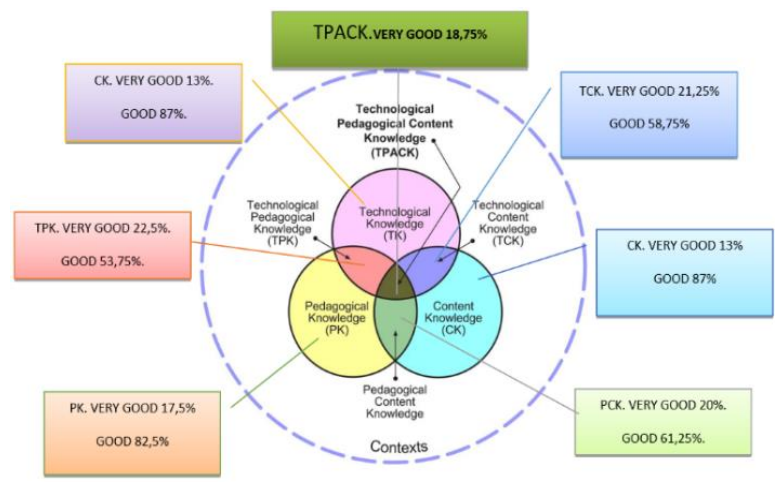

Figure 1 TPACK capability of madrasah teachers.

Meanwhile, many factors affect the madrasah teachers' TPACK, they are as follows:

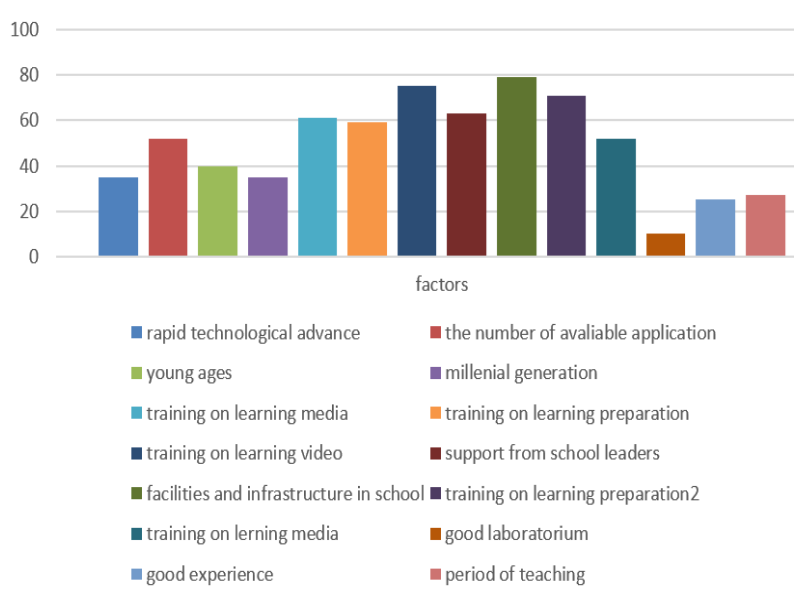

Figure 2 The factors that affect the madrasah teachers' TPACK.

The factors that affect the TPACK level of madrasah teachers in East Java who took part in PPG service of LPTK at UIN Sunan Ampel Surabaya are rapid technological advances, the number of available applications, the teachers who are including into young ages, the millennial generation category and participating

Table 2. TPACK ability level of madrasah teachers based on the learning video

\begin{tabular}{|c|c|c|c|c|c|c|c|}
\hline No & Indicator & \multicolumn{5}{|c|}{ Score/ Percentage } & \multicolumn{2}{c|}{ Total } \\
\hline & & 1 & 2 & 3 & 4 & 5 & \\
\hline 1 & CK & - & - & - & $70(87 \%)$ & $10(13 \%)$ & $80(100 \%)$ \\
\hline 2 & PK & - & - & - & $66(82,5 \%)$ & $14(17,5 \%)$ & $80(100 \%)$ \\
\hline 3 & TK & - & - & - & $61(76,25 \%)$ & $19(23,75 \%)$ & $80(100 \%)$ \\
\hline 4 & PCK & - & - & $15(18,75 \%)$ & $49(61,25)$ & $16(20 \%)$ & $80(100 \%)$ \\
\hline 5 & TCK & - & - & $16(20 \%)$ & $47(58,75 \%)$ & $17(21,25 \%)$ & $80(100 \%)$ \\
\hline 6 & TPK & - & - & $19(23,75 \%)$ & $43(53,75 \%)$ & $18(22,5 \%)$ & $80(100 \%)$ \\
\hline 7 & TPACK & - & - & $17(21,25 \%)$ & $48(60 \%)$ & $15(18,75 \%)$ & $80(100 \%)$ \\
\hline
\end{tabular}


in various trainings, the support from school leaders, also facilities and infrastructure in schools.

\subsection{Discussion}

The ability of 80 madrasah teachers in East Java varies widely. This is because it is influenced by several factors. The TPACK ability of madrasah teachers is very good at $18.75 \%$ and $60 \%$ is good. This is influenced by the field of science, teaching experience, teacher participation in training to increase human resource capacity, and also the large number of young teachers who are included in the millennial generation. This is very helpful in mastering the technology, material, and pedagogy of madrasah teachers $[12,13]$. This is different from Hanik Maslicatin's research which states that the teacher's TPACK ability is still low. This is because those who are being studied are still prospective teacher students while the object of this research is PPG students who are experienced madrasah teachers. Meanwhile, the capability of Content Knowledge (CK) of good madrasah teachers reaches $87 \%$. This is much influenced by the suitability of the teacher's scientific field with the subjects he/she teaches, as well as the available facilities and infrastructure. Furthermore, the capability of teachers in terms of Pedagogy Knowledge (PK) is very good $(17.5 \%)$ and good at $82.5 \%$. The results of this study on the ability of Content Knowledge and Pedagogy Knowledge are not much different from Nevrita's research [5] [14-17].

This is somewhat influenced by the experience of teaching and the insight of teachers in participating in various training to increase the capacity of madrasah teachers. While the ability of madrasah teachers in terms of Technology Knowledge (TK) can be influenced by the number of young teachers who are millennials. The millennial generation is very close and familiar with the rapid development of technology $[18,19]$. In addition to these factors, as the study of the results of previous research, Syarifuddin stated that there are also factors that influence teacher competence, namely professional competence, skill competence, work motivation, leadership where teachers work, and teacher attitudes towards their profession [20-23]. The factors that support the TPACK ability of madrasah teachers the most are facilities, infrastructure in schools, and training in making learning videos. This is because the teachers studied are mostly teachers from private madrasah, not public madrasas. The results of this study indicate that the TPACK ability of madrasah teachers is still at a good level, not very good. This shows that there is still a need for mentoring and training to improve their TPACK abilities in the learning and teaching process.

\section{CONCLUSION}

The ability of madrasah teachers in East Java participating in the Professional Teacher Education
Program (PPG) at the Institute of Teachers' Education (LPTK) UIN Sunan Ampel Surabaya to have very good Technological Pedagogical and Content Knowledge (TPACK) is still limited to 18.75 percent, according to the results of the data exposure and research discussion. Meanwhile, 60 percent of participants had good TPACK ability, while 21.25 percent had moderate or quite TPACK ability. Many variables influence this, including rapid technology advancements, the availability of numerous applications, youthful age as a part of the millennial generation, support from school leaders, participation in various training, school infrastructure, and work experience. The percentage of teachers with TPACK abilities in the "quite" or "moderate" category is still relatively high, at 21.25 percent. Therefore, the author highly recommends that the ability of madrasah teachers to master TPACK still needs to be improved. Relevant parties such as the Ministry of Religious Affair, Head of Madrasah, Deputy Head of Madrasah should hold various trainings or workshops on the use of technology, particularly the TPACK abilities of madrasah teachers. For further researchers, they are hoped to be able to research and capture the TPACK abilities of private teachers in private madrasah and public madrasah who teach certain subjects according to their fields.

\section{AUTHORS' CONTRIBUTIONS}

All authors have different roles in the accomplishment of the study. For this manuscript, they contributed equally to the process of drafting, revision, and approval of the final revision.

\section{REFERENCES}

[1] Tirtha, Role of Educational Technologies Utilizing the TPACK Framework and $21^{\text {st }}$ Century Pedagogies: Academics' Perspectives, IAFOR Journal of Education 6(3) (2018).

[2] M. J. Koehler, P. Mishra, What is technological pedagogical content knowledge? Contemporary Issues in Technology and Teacher Education 9(1) (2009) 60-70.

[3] P. Mishra, M. J. Koehler, Technological Pedagogical Content Knowledge: A framework for teacher knowledge. Teachers College Record 108(6) (2006) 1017-1054. DOI: https://doi.org/10.1111/j.14679620.2006.00684.x

[4] Suyamto, Joko, Analisis Kemampuan TPACK Guru Biologi SMA Dalam Menyusun Perangkat Pembelajaran Materi Sistem Peredaran Darah, INKUIRI: Jurnal Pendidikan IPA 9(1) (2020). DOI: https://doi.org/10.20961/inkuiri.v9il.41381 
[5] Nevrita, Analisis Kompetensi TPACK Guru Melalui Media Pembelajaran Biologi SMA, Jurnal Pendidikan Sains Indonesia (Indonesian Journal of Science Education) 8(2) (2020) 203-217.

[6] Kementerian Agama Republik Indonesia, EMIS, 2016.

[7] C. S. Chai, J. H. L. Koh, Changing teachers' TPACK and design beliefs through the Scaffolded TPACK Lesson Design Model (STLDM). Learning: Research and Practice 3(2) (2017) 114-129. DOI: https://doi.org/10.1080/23735082.2017.1360506

[8] A. Rosyid, Technological Pedagogical Content Knowledge: Sebuah Kerangka Pengetahuan Bagi Guru Indonesia di Era MEA, in Prosiding Seminar Nasional Inovasi Pendidikan Inovasi Pembelajaran Berbasis Karakter Dalam Menghadapi Masyarakat Ekonomi ASEAN, 2016, pp.446-454.

[9] Yulisman, Hendra, A. Widodo, Riandi, C. I. E. Nurina, The Contribution of Content, Pedagogy, and Technology on the formation of science teachers", TPACK Ability, Edusains 11(2) (2019) 173-185.

[10] Papanikolaou, Kyparisia, K. Makri, P. Roussos, Learning Design as a Vehicle for Developing TPACK in Blended Teacher Training on Technology Enhanced Learning, International Journal of Educational Technology in Higher Education (2017). DOI: https://doi.org/10.1186/s41239-017-0072-z

[11]A. Prastya, Strategi pemilihan media pembelajaran bagi seorang guru, in Prosiding Temu Ilmiah Nasional Guru (TING) VIII, Balai Sidang Universitas Terbuka (UTCC), 2016, pp. 294-302.

[12] Rahmadi, I. Fitri, TPACK: Kerangka Pengetahuan Guru Abad 21, Jurnal Pendidikan Kewarganegaraan Journal of Civics and Education Studies 6(1) (2019).

[13]I. F. Rahmadi, E. Hayati, A. Nursyifa, Comparing pre-service civic education teachers' TPACK confidence across course modes: insights for future teacher education programs, Research in Social Sciences and Technology 5(2) (2020) 113-133.

[14]Mutiani, TPACK: A Discursions in Learning Innovation on Social Studies, The Innovation of Social Studies Journal 2(2) (2021) 135-142.

[15]E. Baran, Uygun, Putting TPACK in Action: An Integrated TPACK -design-based learning (DBL) Approach Australian Journal of Educational Technology 32(2) (2016). DOI: https://doi.org/10.14742/ajet.2551

[16] Rahayu, Sri, Technological Pedagogical Content Knowledge (TPACK) Integrasi ICT dalam
Pembelajaran IPA Abad 21, in Prosiding Seminar Nasional Pendidikan IPA IX tahun 2017, TPACK: Optimalisasi Pemanfaatan ICT untuk Meningkatkan Profesionalisme Guru dalam Pembelajaran IPA di Era Digital, 2017.

[17] Raygan, Ali, S. Moradkhani, Factors Influencing Technology Integration in an EFL Context: Investigating EFL Teachers'Attitudes, TPACK Level, and Educational Climate, Computer Assisted Language Learning, (2020). DOI: https://doi.org/10.1080/09588221.2020.1839106

[18] Huriyah, Lilik, Peer Dialogue as an Effective Way for Teaching Speaking: Indonesia EFL Students'Voices, in Proceedings og the International Conference on English Language Teaching (ICONELT 2019), 2019.2 DOI: https://doi.org/10.2991/assehr.k.200427.046

[19]Boonsue, Worasiri, Factors Influencing the Technological Pedagogical Content Knowledge (TPACK) of English Teachers in Primary Schools, Chiang Mai Primary Educational Service Area 1, Turkish Journal of Computer and Mathematics Education 12(8) (2021) 2983-2990.

[20] Adulyasas, Lilla, Measuring And Factors Influencing Mathematics Teachers'technological Pedagogical And Content Knowledge (TPACK) in three Southernmost Provinces, Thailand, AIP Conference Proceedings, 1868 (2017) 050032. DOI: https://doi.org/10.1063/1.4995159

[21] Koh, Joyce, TPACK Concept and Practices, in: Proceeding The $2^{\text {nd }}$ International Conference on Teacher Training and Education Sebelas Maret University, 2(1), 2016.

[22] Sojanah, Janah, Suwatno, Kodri, A. Machmud, Factors Affecting Teachers' Technological Pedagogical and Content Knowledge (A Survey on Economics Teacher Knowledge), Cakrawala Pendidikan 40(1) (2021). DOI: https://doi.org/10.21831/cp.v40i1.31035

[23] Voithofer, Rick, M. J. Nelson, A. Caines, Factors that influence TPACK adoption by teacher educators in the US, Education Technology Research Development 67 (2019) 1427-1453. DOI: https://doi.org/10.1007/s11423-019-09652-9 